Тетяна РОЗВАДОВСЬКА, orcid.org/0000-0003-0631-4417

аспірант кафедри соиіальної педагогіки Начіонального педагогічного університету імені М. П. Драгоманова (Київ, Україна) rozvadovska@uси.edu.иа

Марта БРАТЧЕНКО, студентка 4-го курсу напряму підготовки «Соціальна педагогіка» ВНЗ «Украӥнський католииький університет» (Львів, Украӥна) bratchenko@uси.edu.ua

\title{
ВПЛИВ НАСТАВНИЦТВА НА ФОРМУВАННЯ ТА РОЗВИТОК ДІТЕЙ, ЩО ПЕРЕБУВАЮТЬ В ІНСТИТУЦЙНИХ ЗАКЛАДАХ ОПІКИ
}

У статті розкрито зміст такого поняття, як наставництво, його форми та напрямки. Здійснено аналіз наставнииької діяльності закордонних організаиій: Big Brothers Big Sisters of America, Education for All Children, The Mentoring Project. Проаналізовано вітчизняний досвід наставництва. Визначено етапи розвитку наставнищьких стосунків. Висвітлено основні напрями та форми наставництва. Представлене авторське опитування наставників, підопічних та вчителів та дослідження організації Big Brothers Big Sisters of America щзодо ефективності наставництва.

Ключові слова: наставник, наставництво, програми наставниџтва, напрямки наставництва, форми наставництва, корпоративне наставництво, виховання.

Tetyana ROZVADOVSKA, orcid.org/0000-0003-0631-4417 Postgraduate student at the Department of Social Pedagogy National Pedagogical Dragomanov University (Kyiv, Ukraine) rozvadovska@ucu.edu.ua

Marta BRATCHEKO, Student at the Department of General and Social Pedagogy The Ukrainian Catholic University (Lviv,Ukraine)bratchenko@ucu.edu.ua

\section{THE INFLUENCE OF THE MENTORING ON FORMATION AND DEVELOPMENT OF CHILDREN IN THE RESIDENTIAL INSTITUTIONS}

The paper presents the concept of mentoring in Ukraine and foreign countries. The authors are analyzing the mentoring practice of foreign organizations such as "Big Brothers Big Sisters of America" (USA), "The Mentoring Project" (USA) and "Education for All Children" (Kenya). "Big Brothers Big Sisters of America" has five main programs of the mentoring: "Community-Based Mentoring", "Mentoring for Military Children", "Big in Blue", "School-Based Mentoring", "Mentoring for Children with Incarcerated Parents". "The Mentoring Project" supports children and young people in need. In organization "Education for All Children" the mentors support their adjustment from adolescence to young adulthood. The mentors help students build a plan for success throughout their university studies and beyond.

The authors are analyzing the legislative acts of Ukraine aimed at mentoring; projects of mentoring in Ukraine; investigates stages of a mentoring relationship, forms and direction of mentoring. The mentoring project "One Hope" has been started in 2009 in Ukraine. Other one mentoring project "Education breaks barriers" has been started in 2015 year in Lviv. The purpose of the project is to promote general development of the children, their social competencies and help them to obtain education, to enter university or college. The project "Education breaks barriers" was represented in Ukrainian Catholic University in 2016 year for students. Students can join to the project (be a mentor for child) only after special studying. Stages of mentor relationship include: introduction; staging of goals; achieving goals; the end of a mentoring relationships. The main forms of mentoring are following: individual mentoring, mentoring in the group, mentoring via e-mail. A new form of the mentoring is "Corporate Mentoring" in Ukraine. "Corporate Mentoring" involves engaging socially responsible business in mentoring. The purpose of "Corporate mentoring" is to help child to determine the profession in future. The direction of mentoring is assistance in the education and development of a child, assistance in the successful socialization of children and professional orientation. 
The authors are investigating the influence of the mentoring on formation and development of children. The influence of the mentoring on formation and development of children is defined by means of questionnaires for mentors, teachers and children. The authors analyze the research data on the effectiveness of mentoring of the "Big Brothers Big Sisters of America".

Key words: mentor, mentoring, forms of mentoring, direction of mentoring, "Corporate Mentoring”.

Постановка проблеми. Для України проблема сирітства залишається актуальною, значного масштабу набуває такий феномен, як соціальне сирітство. Даний феномен зумовлений відмовою або відстороненням батьків від виховання власних дітей. Такі діти виховуються переважно в інституційних закладах опіки. Відомо, що виховання дитини в такому закладі, як правило, має негативне відображення в подальшому iï житті. За даними проекту наставництва «Одна Надія», більшість випускників інтернатних закладів поповнюють ряди безхатченків, злочинців, страждають від алко- та наркозалежності. Кожен 7-мий випускник здійснює спробу суїциду. І лише 1\% випускників вступає у ВНЗ. (Одна Надія, 2017).

Проблема підготовки до самостійного життя дітей сиріт та дітей, що позбавлені батьківського піклування, активно обговорюється як на місцевих рівнях, так і на державному. У своєму інтерв'ю УНІАН уповноважений президента України 3 прав дитини, М. Кулеба зауважує, що станом на сьогодні в закладах інтернатного типу проживає близько 116 тис. дітей, серед яких 10\% - статусні діти, а 90\% - діти, які мають батьків. Він акцентує увагу на наставництві як на одному з ефективних методів підготовки вихованців закладів інтернатного типу до самостійного життя. Даний метод широко використовується в багатьох країнах світу (УHIAH, 2016).

У 2016 році був прийнятий Закон «Про внесення змін до Закону Україну «Про забезпечення організаційно правових умов соціального захисту дітей-сиріт та дітей, позбавлених батьківського піклування〉 щодо наставництва. 4 липня 2017 року Кабінет Міністрів України видає постанову «Деякі питання здійснення наставництва над дитиною», в якій зазначається, що наставником може бути особа, що пройшла відповідний курс підготовки і отримала висновки щодо впровадження діяльності з організації наставництва.

Аналіз досліджень. Проблема наставництва знайшла відображення в багатьох сучасних дослідженнях у таких аспектах: розгляд наставництва як форми підготовки дітей-сиріт та дітей, позбавлених батьківського піклування до самостійного життя (В. Грицанюк); як форми підтримки випускників закладів інтернатного типу (О. Байдарова); як технологію супроводу дітей - сиріт та дітей, які позбавлені батьківського піклування (3. Бон- даренко). Водночас постінтернатне наставництво як технологія соціальної роботи стала предметом вивчення таких науковців, як О. Алтинцева, Н. Залигіна та інші.

Аналіз наукових літературних джерел свідчить, що наставництво не $\epsilon$ новим феноменом у роботі з дітьми, які виховуються в закладах інтернатного типу, проте фундаментальних досліджень iз даної проблематики $є$ вкрай мало, тому вплив наставництва на формування та розвиток особистості дітей, що виховуються в закладах інтернатного типу, потребує більш грунтовного вивчення.

Мета статті - проаналізувати вплив наставництва на формування та розвиток особистості дітей, що перебувають в інституційних закладах опіки.

Виклад основного матеріалу. За кордоном ідея наставництва впроваджується з 1904 року, коли молодий клерк Нью-Йоркського суду на ім'я Ернест Култер помітив, що все більше дітей притягуються до адміністративної та кримінальної відповідальності. Причиною цього феномену, на його думку, було те, що діти не мали соціально схвальних взірців для наслідування. Е. Култер вирішив знайти добровольців, які готові присвятити дитині свій час, допомогти формуванню соціально схвальної поведінки та ціннісних орієнтацій, стати значущою особою, взірцем для наслідування. Так започатковується організація «Big Brothers Big Sisters of America» (BBBS), яка діє сьогодні не тільки на теренах США. Дана організація об'єднює добровольців - наставників різних категорій дітей по всьому світу (BBBS, 2018).

Станом на сьогодні в організації діє декілька програм наставництва: наставництво на базі громади (Community-Based Mentoring) - модель індивідуального наставництва, коли підопічний та наставник проводять час разом за бесідами, прогулянками тощо; наставництво для дітей військовослужбовців (Mentoring for Military Children), надається підтримка не тільки дітям, але й їх сім'ям та наставникам; програма «Big in Blue» - залучення поліції до наставництва, формування довірливих стосунків між правоохоронними органами, дітьми та їх сім'ями; наставництво в школі (School-Based Mentoring), в ролі наставників виступають вчителі. Метою цієї програми є допомогти дитині розкрити свій потенціал; до наставництва дітей, батьки яких перебувають у пенітенціарних уста- 
новах (Mentoring for Children with Incarcerated Parents), дуже часто залучаються представники релігійних організацій (BBBS, 2018).

Загалом, на теренах США наставництво $\mathrm{\epsilon}$ досить розповсюдженим явищем, крім організації «Big Brothers Big Sisters of America», наставництвом дітей та молодих людей займається така організація як «The Mentoring Project», гаслом якої $\epsilon$ «Кожна дитина потребує наставника». За даними дослідження цієї організації, в США проживає близько 25 млн. дітей та молодих людей, які не мають батьків або мають таких, що ухиляються від виконання своїх батьківських обов'язків. Такі діти, як свідчить проведене організацією дослідження, більш схильні до вживання алкогольних напоїв, наркотичних речовин, частіше здійснюють правопорушення та мають більшу імовірність виключення $з$ освітніх закладів. «The Mentoring Project» здійснює свою діяльність й поза межами США. Організація займається підготовкою наставників по усьому світу, понад 4000 людей вже пройшли відповідні тренінги. До кінця 2020 року наставницький склад організації мав би становити близько 10 тисяч людей (The Mentoring Project, 2018).

Цікавий досвід, на наш погляд, має кенійська організація «Education for All Children» («EfAC»), яка здійснює наставницький супровід і після закінчення школи-інтернату. Крім того, «EfAC» підтримує талановитих учнів, надаючи їм стипендії на навчання в коледжах. Наставники допомагають молодим людям адаптуватись у новому середовищі, спільно розробляють плани успіху в навчанні та подальшому житті вихованця. За підтримки «EfAC» сотні учнів мають змогу закінчити школу, вступити в коледж та знайти роботу. Саме застосування комплексного підходу вирізняє цей проект посеред інших (EfAC, 2018).

Практика залучення наставників до виховання різних категорій дітей та молодих людей досить широко використовується у всьому світі. Програми наставництва діють незалежно від місця проживання дитини чи молодої людини. На даний час закордоном існують програми наставництва для молодих людей, які проживають окремо, a наставники здійснюють їх супровід та підтримку. Даний досвід є дуже цікавим для України в контексті процесу деінституціалізації.

Український досвід наставництва $\epsilon$ дещо скромнішим за закордонний. Не дивлячись на те, що Закон «Про внесення змін до Закону Україну «Про забезпечення організаційно-правових умов соціального захисту дітей-сиріт та дітей, позбавлених батьківського піклування» був прийнятий лише у 2016 році, наставництво в України розвивається з 2009 року. Беручи за основу досвід організації «BBBS», за підтримки альянсу «Україна без сиріт» та комісії УГКЦ у справах родини розпочинається проект наставництва «Одна Надія». Станом на сьогодні «Одна Надія» має понад 150 успішних історій своїх вихованців. Крім того, проект співпрацював із Київською службою в справах дітей, і результатом цієї співпраці стала розробка методології «Формування навичок самостійного життя в дітей-сиріт та дітей, позбавлених батьківського піклування, які перебувають в установах інституційного виховання».

Із 2011 року керівники проекту проводять навчання за даною методологією для всіх, хто хоче стати наставником або започаткувати подібний проект у своєму місті чи селищі (Проект наставництва, 2018).

Проекти наставництва поступово поширюються по всій Україні. Зокрема, у Львові з 2013 року за підтримки Комісії УГКЦ у справах родини, відділу в справах дітей Львівської міської ради, Центру опіки сиріт УГКЦ та Благодійного фонду «Малятко» проводяться тренінги 3 наставництва для всіх бажаючих допомогти дітям-сиротам і дітям, що позбавленні батьківського піклування (ЛМР, 2013).

Реалізація даного проекту наставництва розпочалась із львівської загальноосвітньої школи інтернату № 2. Із 2015 року в даному навчальному закладі, за підтримки фондів Omnis Foundation (США) та Sublimitas (США), розпочався проект «Освіта долає бар'єри», який в основному спрямований на підготовку випускників інтернатного закладу до ЗНО та вступу у ВНЗ. Загалом, основними напрямками наставництва $€$ : допомога в навчанні та всебічному розвитку дитини; формування в дітей навиків самостійного життя; профорієнтація підлітків.

У жовтні 2016 проект «Освіта долає бар'єри» був презентований у ВНЗ «Український католицький університет» із метою залучення студентів вишу до наставництва. Відбір проходить у декілька етапів: написання мотиваційного листа, подача резюме на розгляд засновниць фондів, після цього студент проходить онлайнспівбесіду. У співпраці з проектом наставництва «Одна Надія» комісією УГКЦ у справах родини за підтримки організацій "Omnis" (США) та "Sublimitas" (США) для студентів, які бажають стати наставником для дитини, що навчається в інтернатному закладі, проводяться навчальні тренінги, після яких вони стають наставниками для дітей із львівської загальноосвітньої школи-інтер- 
нату № 2. Зауважено, що кожного року кількість бажаючих стати наставниками серед студентської молоді збільшується.

Є. Смалем визначено, що розвиток наставницьких взаємовідносин відбувається в чотири етапи:

1. Знайомство. На цьому етапі наставник та дитина знайомляться та визначають спільні інтереси, цінності тощо. На даному етапі важливо встановити довірливі стосунки, оскільки дитина спочатку може й не довіряти наставникові та намагатись маніпулювати ним задля досягнення своїх певних цілей. Наставник повинен бути уважним та щирим. Даний етап може тривати до 6 зустрічей. Крім того, важливим є пояснити дитині, скільки часу будуть тривати їх зустрічі і наставництво загалом (у випадку наставництва студентами за підтримки організацій "Omnis" (США) та "Sublimitas" (США) наставництво триває протягом одного року). Про важливі справи наставникові потрібно попереджати дитину на початку зустрічі. Бажано зробити календар, куди буде внесено канікули, робочі поїздки, вихідні та інші дні, коли наставник не буде мати змоги прийти до дитини.

2. Постановка цілей, написання плану взаємодії. Важливою є постановка цілей разом із дитиною, а не нав'язування їх наставником. Наставник та дитина обговорюють очікування один одного від зустрічей. Встановлюються короткострокові та довгострокові цілі та прописується індивідуальний план, в якому зазначаються особисті, освітні, соціальні та інші цілі. Постановка цілей також вимагає аналізу результатів та обговорення успіхів та невдач.

3. Досягнення цілей. Поступове виконання поставлених цілей. На цьому етапі, як правило, відбувається зміцнення стосунків.

4. Завершення взаємодії. Наставник та дитина обговорюють майбутні перспективи, аналізують досягненні результати. Важливим є, щоб після завершення наставницьких стосунків у дитини повинно сформуватись відчуття завершеності даного процесу. Розуміння дитиною того, що спілкування і сам процес наставництва був успішним, і вона далі може самостійно досягати цілей. (Смаль та ін., 2014: 14-18).

Є. Смаль, І. Сацюк, Ю. Удовенко виділяють такі форми наставництва:

1. Індивідуальне наставництво, що передбачає зустрічі наставника та дитини не менше чотирьох разів на місяць, не менше року.

2. Наставництво групі передбачає взаємодію одного або декількох дорослих із групою дітей. Взаємодія в основному планується протягом навчального року з передбаченням часу для особистого спілкування.

3. Наставництво за допомогою електронної пошти передбачає спілкування одного дорослого 3 однією дитиною, яке відбувається не менше, ніж раз на тиждень і триває від півроку і довше. Крім того, передбачаються й особисті зустрічі.

На даний час популярності набуває корпоративне наставництво, до якого долучається відповідальний бізнес. Основною метою такого наставництва $\epsilon$ розширити коло професійних можливостей через наставницькі стосунки, майстер-класи та стажування дітей, що виховуються в інтернатних закладах та кризових сім'ях.

22 травня у м. Львів за підтримки БФ «Українська Галицька Фундація» відбувся форум корпоративного наставництва «Я професія» для дітей із інтернатів (22 травня «Я професія», 2018).

На даному форумі зустрілись 16 компаній, які представляли різні професії, та 105 дітей соціально незахищених категорій. Кожен учасник отримав брошурку з вимогами та середньою заробітною платою кожної професії. Крім того, після закінчення форуму діти, випускники інтернатних закладів, матимуть можливість ближче ознайомитись із професією через стажування, практику або навчання.

Є. Смалем у посібнику «Наставництво крок за кроком. Посібник для небайдужих дорослих» визначено основні напрямки, за якими наставники працюють зі своїми підопічними, а саме:

1. Допомога в навчанні та всебічному розвитку дитини. Даний напрямок передбачає допомогу у вдосконаленні академічних, шкільних знань та особистісних уподобань.

2. Сприяння успішної соціалізації дитини. Передбачає організацію змістовного дозвілля, допомогу в підвищені самооцінки, заохочення в застосуванні нових моделей поведінки, розвиток комунікаційних та побутових навичок тощо.

3. Профорієнтація. Передбачає допомогу підліткам у професійному самовизначенні через знайомство підопічних із різними організаціями, обговорення планів на майбутнє, використання особистих контактів для знайомства 3 різними професіями тощо (Смаль та ін., 2014: 9-10).

Таким чином, наставництво можна трактувати як важливу складову частину гармонійного розвитку дитини, набуття позитивного життєвого досвіду через спілкування з наставником, який допомагає їм сформувати ціннісні орієнтири та життєві навички.

Із метою моніторингу ефективності наставницьких стосунків було проведене анкетування 
в школі-інтернаті № 2 міста Львова. В анкетуванні взяли участь учні (21), наставники (5) та педагоги школи (3).

У більшості учні школи спілкуються з наставником понад рік - 13 (61,9\%), менше року $8(38,1 \%) .7(33,3 \%)$ опитаних учнів бачаться зі своїм наставником декілька разів на тиждень, 9 (42,8\%) учнів - кілька разів на місяць, 2 (9,5\%) - один раз на тиждень, і лише один раз на місяць - $3(14,4) \%$. Поза межами школи зі своїми наставниками через соціальні мережі, телефоні розмови спілкуються 15 (71,4\%) вихованців. Із метою визначення напрямків діяльності наставника та підопічного нами було використане питання «Що Вам найбільше подобається робити зі своїм наставником?». Діти мали можливість вибрати декілька варіантів відповідей, які розподілились таким чином: 11 (52,4\%) віддають перевагу іграм, спільним прогулянкам; спілкуванню на різні теми - $6(28,6 \%)$ опитаних; робити домашнє завдання, додатково вивчати щось нове 10 (47,6\%). Цікавим $є$ те, що діти 6-9 років віддають перевагу іграм із наставником, старші діти, 13-17 років, зазначають, що їм більше подобається допомога в навчанні, спільні прогулянки, розмови на різні теми.

Важливим у наставницькій взаємодії є можливість дитини пізнати щось нове, набути самовдосконалення. Це засвідчує той факт, що 15 (71,4\%) опитуваних зазначили, що пізнали багато нового завдяки спілкуванню 3 наставником (частина опитаних учнів зазначали, що навчились бути більш ввічливими, терплячішими, порозумнішали, навчились читати, розв'язувати математичні завдання тощо). 1 (4,8\%) учень зауважив, що більше вдосконалився, ніж навчився нового; $1(4,8 \%)$ зазначив, що на даний момент не навчились нічого нового, варто зауважити, що в анкеті було зазначено, що наставник спілкується з дитиною менше року. 4 (19\%) не змогли дати відповідь на запитання. Нас приємно вразило, що $100 \%$ опитаних учнів висловили бажання продовжувати наставницькі взаємовідносини.

Опитування наставників, які $є$ студентами та учасниками проекту «Освіта долає бар'єри», надало такі результати: декілька разів на тиждень зі своїми підопічними зустрічаються 2 (40\%), декілька разів на місяць 3 (60\%) опитаних; поза межами школи з учнями спілкуються $3(60 \%)$ наставників. Основною мотивацією для участі в проекті «Наставництво», як зазначають респонденти, було бажання допомогти дитині в досягненні ії мрій, поділитись власним досвідом, допомогти дитині в навчанні, допомогти дитині сформувати світогляд, змінити життя дитини на краще тощо. Частина наставників зазначила, що самі багато чого навчились у дітей, розвинули певні моральні чесноти.

Усі респонденти зазначили, що в основному наставництво сконцентроване на допомозі в навчанні, виконанні домашніх завдань, відвідуванні гуртків, додаткових заняттях із підопічним 3 англійською мови, математики тощо. Крім того, наставники допомагають своїм підопічним розвивати їх творчі здібності, розв' язувати певні життєві ситуації, а також організовують змістовне дозвілля (прогулянки містом, відвідування музеїв, читання та обговорення художньої літератури тощо.)

На питання: «Чи помітили Ви зміни у Вашого підопічного протягом взаємодії 3 ним?» 5 (100\%) респондентів зазначили, що помітили зміни. Покращення в соціальній взаємодії, як 3 оточуючими, так і зі своїми наставниками, зауважили 5 (100\%); успіхи в навчанні зауважили 2 (40\%) опитаних; 1 (20\%) наставниця зазначила, що покращились навички самообслуговування. Варто сказати, що одна 3 наставниць зазначила, що їі підопічного всиновили, але вони продовжують підтримувати зв'язок та спілкування.

Основними труднощами в наставницькій взаємодії, на думку респондентів, є подолання бар'єрів під час перших зустрічей, заохочення дитини до навчання, різного види маніпуляції з боку підопічного. Як правило, наставники долали труднощі за допомогою відвертих і щирих розмов 3 підопічним, застосовували інтерактивні методи для заохочення дитини до навчання.

На питання «Що, на Вашу думку, може впливати на процес наставництва?» 2 (40\%) вважають, що вплив має сім'я підопічного та його оточення; 3 (60\%) вважають - взаємостосунки між наставником та підопічним.

5 (100\%) опитаних вважають, що наставництво $\epsilon$ корисним та ефективним для розвитку дитини. Респонденти зазначають, що наставництво допомагає в розвитку здібностей дитини, емоційного інтелекту; сприяє успішній адаптації вихованця поза межами інтернатного закладу.

Продовжувати наставництво виявили бажання 4 (90\%) респондентів, 1 (10\%) наставниця зазначила, що потребує невеликої перерви, але із часом рада би повернулись до наставницької діяльності.

Таким чином, зауважуємо, що опитані наставники допомагають дитині не тільки в навчанні, але й у всебічному розвитку. Щодо змін, варто зауважити, що це індивідуальний процес, який залежить як від дитини, так і від наставника, проте наставники спостерігають позитивні зміни 


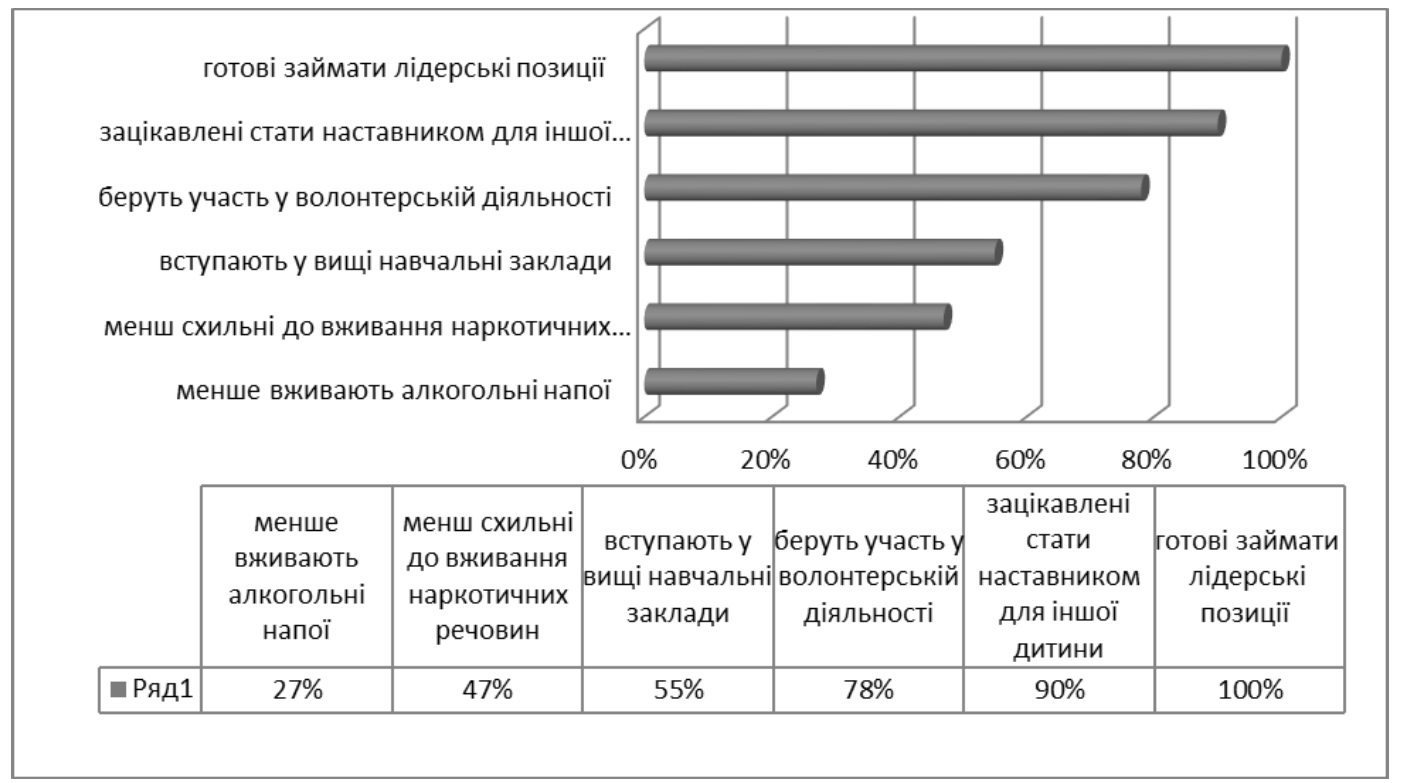

Pис. 1.

у своїх підопічних. Варто зауважити, що процес наставництва не $є$ легким та без труднощів, однією 3 основних $\epsilon$ мотивація дитини до навчання. Усі опитані наставники стверджують, що наставництво $є$ корисним та ефективним, це змінює дитину на краще. Крім того, наставники зазначають, що підопічні також позитивно впливають на їх розвиток як особистостей.

Опитування педагогів надало такі результати: зміни в учнів помітили 2 (66,7\%) педагогів, які проявляються в кращій підготовці домашнього завдання, спілкуванні, відкритості. Респонденти зауважили, що учні намагаються рівнятись на своїх наставників. 1 (33,3\%) педагог зауважив, що для позитивних змін наставникові потрібно більше часу приділяти підопічному. 3 (100\%) педагогів зазначили, що наставництво $є$ корисним та ефективним та розвитку дитини, аргументуючи тим, що це індивідуальна та безпосередня допомога дитині, приклад для наслідування та відчуття своєї значущості для іншої людини. Крім того, респонденти висловили думку, що ефективність наставництва залежить від наставника, який повинен працювати над всебічним розвитком свого підопічного.

Щодо труднощів у процесі наставництва думки педагогів розділились. Одні вважають, що вони виникають, якщо немає систематичних зустрічей та плану індивідуального розвитку дитини, інші, що труднощі в основному виникають у спілкуванні, оскільки наставник не може стати авторитетом для дитини чи не подобатись їй. Також існує можливість непорозуміння наставника та підопічного, що суттєво погіршує взаємо- дію. Щодо впливу різних факторів на успішність наставництва респонденти зазначили, що важливим у процесі наставництва $є$ час, який наставник приділяє підопічному, рівень комунікабельних здібностей, розуміння один одного та авторитетність наставника для підопічного. Крім того, важливим є бажання наставника та підопічного створювати комфортні умови для співпраці, постать наставника, його вміння знайти підхід до дитини. На думку педагогів, наставництво може бути корисним у випадку, якщо наставник достатньо часу приділяє підопічному, займається його всебічним розвитком (походи в музеї, кіно, театри, прогулянки історичними місцями тощо). Щодо труднощів педагоги зазначають майже ті самі що й наставники: непорозуміння, труднощі в налагодженні контакту та спілкуванні тощо.

Таким чином, підсумовуючи опитування, робимо висновок, що наставництво має позитивний вплив на дитину за умови тісної співпраці наставника та підопічного. Для досягнення позитивного результату наставникові потрібно приділяти достатньо уваги своєму підопічному. Крім того, важливим $є$ написання індивідуального плану розвитку, досягнення поставлених цілей. Яке можливе, за умови, систематичних зустрічей та побудові довірливих та дружніх стосунків.

Цікавим щодо ефективності наставництва $\epsilon$ дослідження організації «Big Brothers Big Sisters of America»» (Одна надія, 2017), яке представлено на рис. 1.

Дане дослідження доводить, що якісно побудовані стосунки між наставником та підопічним позитивно впливають на розвиток дитини, іiі пове- 
дінку, життєвий вибір, формування світогляду та ціннісних орієнтацій.

Висновки. Таким чином, проведене опитування, аналіз зарубіжного наставництва та дані дослідження BBBS свідчать про позитивний вплив наставництва на формування та розвиток особистості дітей-сиріт та дітей, що позбавленні батьківського піклування. За кордоном наставництво розвивається 3 початку ХХ ст., діють масштабні проекти щодо наставництва дітей різних вікових категорій, які охоплюють декілька країн. В України наставництво почало розвиватись біля 10 років тому, але вже має певні позитивні результати і потребує подальшого розвитку. Беручи до уваги закордонний досвід, де наставників мають не тільки діти, що виховуються в інституційних закладах опіки, але й діти, що опинились у складних життєвих обставинах, зауважуємо, що розвиток наставництва буде сприяти деінституцілізаційним процесам в Україні. Зазначимо, що в Україні процес деінституціалізації розпочато в 2017 році $з$ прийняттям Національної стратегії реформування інституційного догляду та виховання дітей на 2017-2026 роки.

Перспективними напрямками дослідження даної проблеми $є$ : визначення ролі та місця наставництва в Національної стратегії реформування інституційного догляду та виховання дітей на 2017-2026 роки; можливості подальшого залучення студентської молоді до наставництва та виявлення виховних впливів даного виду діяльності.

\section{СПИСОК ВИКОРИСТАНИХ ДЖЕРЕЛ}

1. Наставництво крок за кроком. Посібник для небайдужих дорослих / О. Смаль, І. Сацюк, В. Андросова [та ін.]. Київ, 2014. 80 с.

2. Микола Кулеба: Сиріт в інтернатах по всій Україні усього 8 тисяч, і всі інші - 98 тисяч - діти, які мають сім’i / УHIAH. 2017. URL: https://www.unian.ua/society/1956921-mikola-kuleba-sirit-v-internatah-po-vsiy-ukrajiniusogo-8-tisyach-a-vsi-inshi-98-tisyach-diti-yaki-mayut-simji.html (дата звернення 25.05.2018).

3. Big Brothers Big Sisters of America. 2018. URL: http://www.bbbs.org (дата звернення 25.05.2018).

4. The Mentoring Project. 2018. URL: http://www.thementoringproject.org (дата звернення 25.05.2018).

5. Education for All Children. 2018. URL: https://educationforallchildren.org (дата звернення 27.05.2018).

6. Проект Наставництва для дітей-сиріт. 2018. URL: https://www.prostir.ua/?organization=proekt-nastavnytstva-dlyaditej-syrit- odna-nadiya (дата звернення 27.05.2018).

7. Львівська міська рада / Соціальна сфера. 2013. URL: http://city-adm.lviv.ua/topic/наставництво (дата звернення 11.06.2018).

8. 22 травня у Львівському палаці мистецтв відбувся I Форум корпоративного наставництва «Я професія» для дітей із інтернатів. / Українська Галицька Фундація. 2018. URL: http://ugf.com.ua/proekt-korporatyvne-nastavnytstvovzhe-na-galychyni (дата звернення 31.08.2018).

9. Одна Надія / Про нас. 2017. URL: http://onehope.com.ua/our-team/ (дата звернення 24.04.2018).

\section{REFERENCES}

1. Nastavnytstvo krok za krokom. Posibnyk dlia nebaiduzhykh doroslykh [Mentoring step by step. Mentoring step by step. A handbook for non-indifferent adults]. / O. Smal, I. Satsiuk, V. Androsova [ta in.]. Kyiv, 2014. 80 s. [in Ukrainian].

2. Mykola Kuleba: Syrit v internatakh po vsii Ukraini usoho 8 tysiach, i vsi inshi - 98 tysiach - dity, yaki maiut simi [Mykola Kuleba: Orphans in boarding schools across Ukraine total 8 thousand, and all others - 98 thousand - children with families]. / UNIAN. 2017. URL: https://www.unian.ua/society/1956921-mikola-kuleba-sirit-v-internatah-po-vsiy-ukrajiniusogo-8-tisyach-a-vsi-inshi-98-tisyach-diti-yaki-mayut-simji.html (25.05.2018). [in Ukrainian].

3. Big Brothers Big Sisters of America. 2018. URL: http://www.bbbs.org (25.05.2018). [in English].

4. The Mentoring Project. 2018. URL: http://www.thementoringproject.org (25.05.2018). [in English].

5. Education for All Children. 2018. URL: https://educationforallchildren.org (27.05.2018). [in English].

6. Proekt Nastavnytstva dlia ditei-syrit [Mentoring project for orphans]. 2018. URL: https://www.prostir.ua/?organization=proekt-nastavnytstva-dlya- ditej-syrit- odna-nadiya (27.05.2018). [in Ukrainian].

7. Lvivska miska rada [Lviv City Council]. / Sotsialna sfera. 2013. URL: http://city-adm.lviv.ua/topic/nastavnytstvo (11.06.2018). [in Ukrainian].

8. 22 travnia u Lvivskomu palatsi mystetstv vidbuvsia I Forum korporatyvnoho nastavnytstva «Ia profesiia» dlia ditei iz internativ. / Ukrainska Halytska Fundatsiia. 2018. URL: http://ugf.com.ua/proekt-korporatyvne-nastavnytstvo-vzhe-na-galychyni (31.08.2018). [in Ukrainian].

9. Odna Nadiia [One Hope]. / Pro nas. 2017. URL: http://onehope.com.ua/our-team/ (24.04.2018). [in Ukrainian]. 